systematically, as the comet is growing lower for northern observers. But as it will not pass the limit of $302^{\circ}, \mathrm{S}$. Decl. the southerly observatories of Europe and all those of the United States will probably be able to follow it as long as it remains visible, and will find comparison stars in Argelander's Zones.

It will not have escaped your notice that all the elements differ from those of 1880 in the same direction in which these differed from those of 1843 .

In the earliest observations made with the large telescope there appeared to be, in the place of the nucleus, a series of bright points following the axial line. The preceding and brightest of these seemed scarcely to exceed the tenth magnitude, and all were connected by intermediate material of somewhat less brilliancy which made it difficult or impossible to count them. $\mathrm{Mr}$. Thome, who has made all the micrometric measurements, thinks that there were certainly not less than five or six, and perhaps more. The appearance was as though the original nucleus had been resolved into a serics of illdefined granules. These have gradually become less and less distinct, until the place of the nucleus, now appears occupied by a line of irregular definition and unequal brightness, about $45^{\prime \prime}$ in length, and of an average width of about 5". All our determinations of position were made for the preceding and brightest of these nodules while they were clearly distinct; and, since then, for the anterior extremity of the bright line, where is a point which is still somewhat brighter than the remaining portions.

Since we are at present overloaded with work, in the preparation of the Zone-Catalogue, and observations are, without doubt, still making in Europe and North America, I will reserve the micrometric determinations until the reductions can be revised.

Those made on the meridian are as follows:-

\begin{tabular}{|c|c|c|c|c|c|}
\hline & & & $\alpha$ & & $\delta$ \\
\hline I 882 , Sept. I8 & $\ldots$ & $\begin{array}{l}\text { h. } \\
\text { I I }\end{array}$ & $\begin{array}{l}\mathrm{m} . \\
20 \\
5 \mathrm{I}^{\circ} 3\end{array}$ & $\ldots$ & 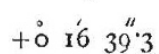 \\
\hline $\begin{array}{l}19 \\
\end{array}$ & ... & I I & 14310 & $\ldots$ & $-03238 \cdot 6$ \\
\hline $2 \mathrm{I}$ & $\ldots$ & I I & $457^{\circ} 9$ & $\ldots$ & - I $5933^{\circ} 2$ \\
\hline
\end{tabular}

\section{DESTRUCTION OF LIFE IN INDIA BY WILD} ANIMALS

$\mathrm{I} \mathrm{N}$ a recent communication $\mathrm{I}$ called attention to the loss of human and animal life in India from snake bites; I now proceed to describe the mortality due to wild animals, which, though much less than the former, is very considerable, and forms an important item in the mortuary returns.

The statement appended shows in detail for each province the number of persons and cattle killed by wild animals, and the number of wild animals destroyed, with the rewards paid for their destruction during the year 1881, as compared with the previous year. The figures are summarised in the following tables:-

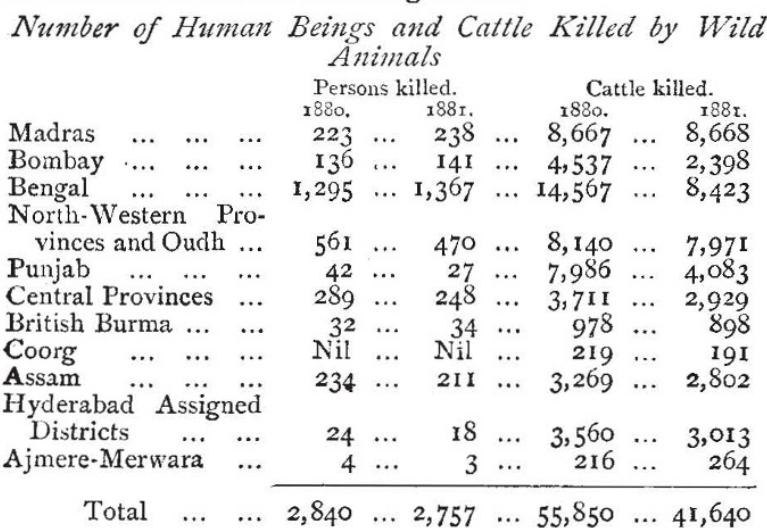

Number of Wild Animals destroyed and Amount of Rezvards Paid

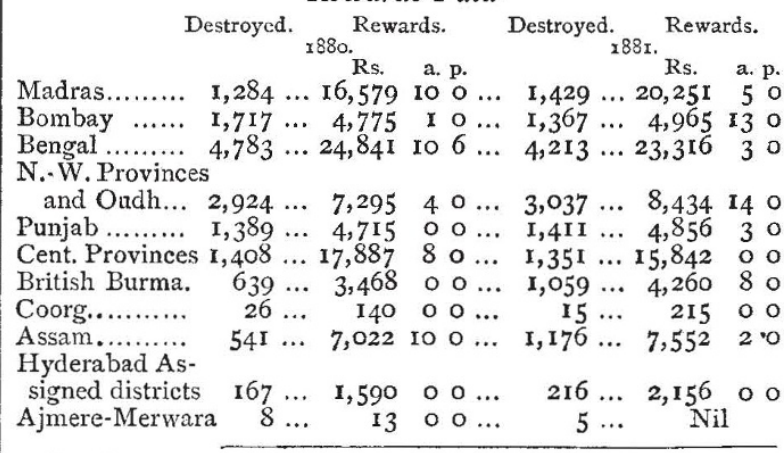

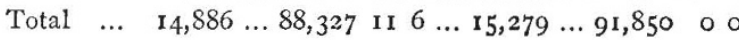

The resolution of Government, dated November 8, 1882, in dealing with this subject, gives the following details, which are so far satisfactory, as they show that organised measures are now being put in force for the destruction of wild beasts, and that already there has been diminution in the loss of human and domestic animal life. As in the case of venomous snakes, the prevention, or at all events diminution of loss of human and domestic animal life from the ravages of wild animals, is a question mainly of time, perseverance, and expenditure of money. The last consideration perhaps may have stood in the way of progress, not that expenditure of rupees either has been or would be grudged, were there certainty that it would overcome the evil, but that there may have been, perhaps is, a natural reluctance to spend public money for what seems an uncertain benefit, as some have regarded a system of rewards for destruction of snakes and wild animals. The Government of India has always evinced a desire to adopt any steps that might reasonably afford hope of relief, and many resolutions by the supreme and local Governments, and considerable expenditure of money wlth this object in view, proves that the authorities have been and are alive to the magnitude of the evil and to the importance of repressing it, and that they have taken measures which in some districts have been attended with a fair amount of success. But the absence of a thoroughly organised system of dealing with the evil, and the desultory and varying methods employed have prevented the attainment of the success that might fairly be expected and would be obtained under better arrangements; and it will not be until some complete organised system have been steadily and perseveringly prosecuted that the desired result will be accomplished. A few years ago (in 1878 ), when calling attention to this subject, I noted that the loss of life from wild animals in 1875 and 1876 had been as follows :-

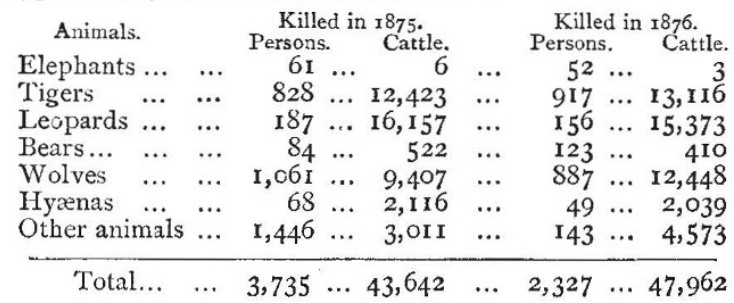

Comparing these returns with that of $1880-8 \mathrm{I}$ it will be observed that the loss of life has not been materially diminished

$$
\begin{aligned}
& \begin{array}{llllll}
1880 & \ldots & \ldots & \ldots & \ldots & \ldots
\end{array} \\
& \begin{array}{lllllll}
1880 & \ldots & \ldots & \ldots & \ldots & \ldots & 2,840 \\
1881 & \ldots & \ldots & \ldots & \ldots & \ldots & 2,757
\end{array} \\
& \begin{array}{lllllll}
1875 & \ldots & \ldots & \ldots & \ldots & \ldots & 3,735
\end{array} \\
& \begin{array}{lllllll}
1876 & \ldots & \ldots & \ldots & \ldots & \ldots & 2,327
\end{array}
\end{aligned}
$$

though there is reason to hope that future yearly reports will be more favourable. 
Registration is now becoming more accurate than it has been, and the returns are probably more reliable than they were, but they do not indicate any marked improvement on the whole. It is evident, however, from the terms of the resolution before referred to, that Lord Ripon is determined to deal vigorously with the evil, and, just as in the case of the poisonous snakes-only, perhaps, more surely - will the result, in time, justify the expenditure which must needs be incurred.

Of the wild animals and venomous snakes which destroy life in India, the wolf and tiger, it will be seen, are the chief offenders among the former, the cobra and bungarus (krait) among the latter. A list of the rewards that have been offered at various times and in different parts of India is appended, but I do not know the amount now offered for each animal, though it is probably much on the same scale. If these rewards be distributed regularly and systematically throughout India, they will probably suffice to insure a steady reduction in the number of noxious animals, and so will diminish a great evil.

"The figures quoted show a decreas 2 during the year under review, as compared with the previous year, both in the number of persons and cattle killed; and, on the other hand, an increase in the number of wild animals destroyed. As was the case in the previous year, the mortality which occurred in Bengal and in the NorthWestern Provinces and Oudh, was far greater than in other provinces. Of the total number of deaths, 2757 were caused by wild animals, the figures for the previous year being 2840 .

The number of persons killed in Bengal (747), and in the North-western Provinces, and Oudh (208) by wild animals other than those specifically named in the returns, was considerable. In future returns the animals which come under the general head "other animals," and which causes in all provinces a very large proportion of the mortality, should be specified in a foot-note, with the number of deaths caused by each kind.

The total number of cattle killed also decreased. This result is chiefly due to the exclusion from the Bengal return of sheep and goats, of which a large number were included in the figures of the year I 880. There has, however, been a marked decrease in the number of cattle killed by wild animals in the Bombay Presidency. In the Punjab, also, the number of cattle killed was considerably less than in the preceding year, but in this province, as in the case of Bengal, the decrease appears to be due to the exclusion of sheep and goats from the returns of the year I88I.

The number of wild animals destroyed was 15,279 , against 14,886 in 1880 . The number of tigers, leopards, bears, and wolves destroyed was $1557,3397,991$, and 4538 respectively, as compared with 1689,3047 , I100, and 4243 in the preceding year; and the number of human beings killed by these animals respectively, amounted to $889,239,75$, and 256 , against $872,26 \mathrm{I}$, 108 , and 347 in the year 1880 .

Of the total amount of rewards paid during the year, Rs 91,850 were awarded for the destruction of wild animals.

In the review of the returns for the year I880 a hope was expressed that endeavours would be made to induce men belonging to the Shikari class to devote themselves specially to the work of destruction in districts which are more than usually infested with wild animals, and Local Governments were authorised to make special arrangements for the experimental employment of such men. From the present reports it appears that the Government of Madras has decided that the employment of a paid corps of Shikaris is undesirable, as the cost of supervision would be excessive, while the employment of such a corps would discourage lozal Shikaris. On this point the Governor-General in Council desires to remark that where local Shikaris exist it is very desirable that every en- couragement should be held out to them, and that in such cases it is preferable to trust to fixed, certain, and prompt payments according to results, as the most effective way of inducing the Shikaris to devote themselves to the work. At the same time certain tracts of country exist in which the special and temporary employment of men from outside may be very useful and expedient, and the reports show that the adoption of this plan has in some cases been followed by satisfactory results. For instance, in the Futehpore district, in the North-Western Provinces, the entertainment of a body of special Shikaris resulted in the destruction of a considerable number of wolves with which that district was infested. In Dinapore, in the Lower Provinces, also, professional hunters were engaged during the closing month of the year for the destruction of tigers.

"In the Central Provinces the ravages committed by tigers in the Balaghat and Seoni districts necessitated the offer of enhanced rewards for their destruction, and the district officer of Seoni has endeavoured to organise a special expedition of shikaris for the purpose of hunting down the animals, and has provided the shikaris with ammunition. Licenses under the Arms Act appear to have been more freely given than hitherto to persons who require arms for protecting themselves and their cattle and crops from the attack of wild animals, but the Governor-General in Council desires to take the opportunity of expressing a hope that this matter will be carefully kept in view by Local Governments and Administrations in order that every possible facility may be offered to cultivators and others for obtaining such licences in districts in which wild beasts are more than usually abundant."

\section{Wild Animals destructive to Life in India}

\section{Carnivora} Felide

$$
\begin{aligned}
& \text { Felis-F. leo } \\
& \text { F. tigris } \\
& \text { F. pardus } \\
& \text { F. jubata }
\end{aligned}
$$

Lion

Tiger

Leopard

Hunting Leopard

Hyæna-H. striata

Canis-C. pallipes

C. aureus Hycenince

Striped Hyæna

$$
\text { Canide }
$$

Wolf

Urside

Brown Bear

Black Bear

Ursus-U. isabellinus

U. tibetanus

Sloth Bear.

U. labiatus

UNGULATA

Elephantidco

Elephas-E. indicus

Rhinoceros-R, indicus

Elephant

Rhinocerus

Sus-S. indicus

Wild Boar

Bovince

Bi:on, gaur

Gavæus-G. gauri

Bubalus - B. arni

Buffalo, arna

SAURIA

Crocodilidie

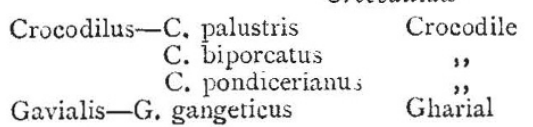

Pisces

rarcharide

Carcharias-C. gangeticus Groundshark of Ganges 


\section{Poisonous Snakes of India}

Those marked with an * are most deadly.

Those marked with a + are most common among the most deadly.

\section{Poisonous Colubrine Snakes} Elapide
I. Naja
2. Ophiophagus
3. Bungarus
4. Xenurelaps
5. Callophis

N. tripudians $\dagger$, cobra, several varieties

O. elaps *, hamadryas

B. cæruleus $t$, krait

B. fasciatus, sankni

$\mathrm{X}$. bungaroides

C. intestinalis and several other spec'es

Hydrophida, or Sea Snakes (all deadly)
I. Platurus
2. Hydrophis
P. scutatus, P. Fischeri
3. Enhydrina
cyanocincta, and several other species
4. Pelamis
E. hengalensis
P. bicolor

Viperine Snakes

Crotalide, or Fit Vipers

I. Trimeresurus

2. Peltopelor

3. Halys

4. Hypnale

I. Dabcia

2. Echi
$\mathrm{T}$. gramineus and several other species

P. macrolepis

H. himalayanus

H. nepa

Viperida, or true Vipers

D. russelliit, Chain Viper, Tic-polonga

$\mathrm{E}$. carinata $\uparrow$, Phoorsa snake, Afaë, Kuppur

The following is a scale of the rewards offered in different parts of India, at different times, for wild beasts and snakes :-

\section{Tigers}

\begin{tabular}{|c|c|c|c|c|c|c|}
\hline \multirow[b]{2}{*}{ Bengal } & & \\
\hline & $\ldots$ & $\cdots$ & $\cdots$ & $\cdots$ & $\ldots$ & $12 \frac{1}{2}$ io 50 \\
\hline Berar & $\ldots$ & $\ldots$ & $\ldots$ & $\ldots$ & $\ldots$ & 10,20 \\
\hline Bombay & $\ldots$ & $\cdots$ & $\cdots$ & $\ldots$ & $\ldots$ & 6,60 \\
\hline Burmah & & $\ldots$ & $\cdots$ & $\ldots$ & $\cdots$ & 5,20 \\
\hline \multicolumn{3}{|c|}{ Central Provinces } & $\cdots$ & $\cdots$ & $\cdots$ & $10,, 100$ \\
\hline \multicolumn{3}{|c|}{ Hyderabad $\quad \ldots$} & $\ldots$ & $\ldots$ & $\cdots$ & 20 \\
\hline Madras & $\ldots$ & $\cdots$ & $\cdots$ & $\cdots$ & $\cdots$ & 50 to 500 \\
\hline My:ore & $\cdots$ & $\ldots$ & $\ldots$ & $\ldots$ & $\ldots$ & \multirow{2}{*}{$\begin{array}{l}35 \\
\text { 10 }\end{array}$} \\
\hline Nerth-W & est I & vinces & $\cdots$ & $\ldots$ & $\ldots$ & \\
\hline Oudh & $\ldots$ & $\ldots$ & $\ldots$ & $\ldots$ & $\ldots$ & None \\
\hline Punjab & $\ldots$ & $\ldots$ & $\ldots$ & $\ldots$ & $\ldots$ & None \\
\hline \multirow{2}{*}{\multicolumn{3}{|c|}{ Rajpootana }} & $\ldots$ & $\cdots$ & $\ldots$ & Io to 15 \\
\hline & & & \multicolumn{3}{|c|}{ Lion } & \\
\hline
\end{tabular}

The only record of which I find official mention, is 25 rupees in Kotah.

\section{Panthers, Lfopards, Cheetahs}

\begin{tabular}{|c|c|c|c|c|c|c|c|}
\hline & & & & & & & upees. \\
\hline Bombay & $\cdots$ & $\cdots$ & $\cdots$ & $\cdots$ & $\cdots$ & & to 10 \\
\hline Burmah & $\cdots$ & $\cdots$ & $\cdots$ & $\cdots$ & $\cdots$ & 3 & \\
\hline Hyderabad & $\ldots$ & $\begin{array}{l}\cdots \\
\cdots\end{array}$ & $\cdots$ & $\begin{array}{l}\cdots \\
\cdots\end{array}$ & $\cdots$ & 5 & IO \\
\hline Madras & $\ldots$ & $\ldots$ & $\ldots$ & $\ldots$ & $\ldots$ & & 25 \\
\hline Mycore & $\ldots$ & $\ldots$ & $\ldots$ & $\ldots$ & $\ldots$ & & 15 \\
\hline North-West & & vinces & $\ldots$ & $\ldots$ & $\ldots$ & & 5 \\
\hline Rajpootana & & $\ldots$ & $\ldots$ & $\ldots$ & $\ldots$ & 8 & to 10 \\
\hline Central Pro & ovi: c & $5 . .$. & $\ldots$ & $\ldots$ & $\ldots$ & 5 & \\
\hline
\end{tabular}

\section{WOLVES}

\begin{tabular}{|c|c|c|c|c|c|c|}
\hline \multirow[b]{2}{*}{ Bengal } & & & & & & Rupees \\
\hline & $\ldots$ & $\ldots$ & $\ldots$ & $\cdots$ & $\ldots$ & 5 to $2 C$ \\
\hline Berar & $\ldots$ & $\ldots$ & $\ldots$ & $\ldots$ & $\ldots$ & 3, \\
\hline Bombay & $\ldots$ & $\ldots$ & $\ldots$ & $\ldots$ & $\ldots$ & 4 \\
\hline Central & Provinces & $\ldots$ & $\ldots$ & ... & $\ldots$ & 2 to \\
\hline adras & & $\ldots$ & $\ldots$ & ... & $\ldots$ & 5 \\
\hline the $\mathrm{W}$ & Vest Prov & inces & $\cdots$ & $\cdots$ & $\cdots$ & 5 \\
\hline 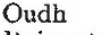 & $\ldots$ & $\ldots$ & $\ldots$ & $\ldots$ & $\ldots$ & to \\
\hline poot: & ana... & $\ldots$ & & $\ldots$ & & 5 \\
\hline
\end{tabular}

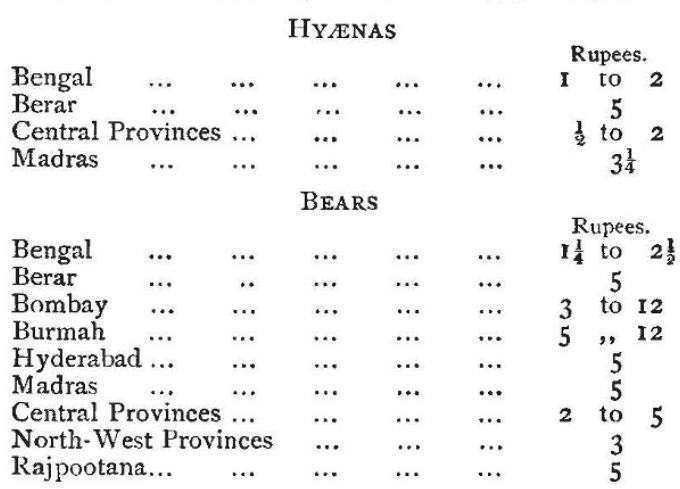

SNAKES (Species not reported)

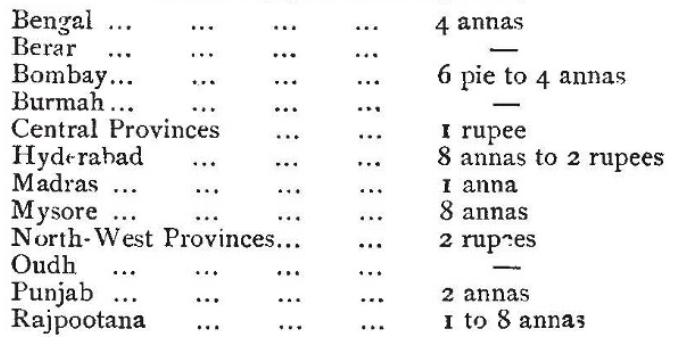

No rewards appear officially proclaimed for elephants, buffaloes, or bisons. In cases of notorious rogue elephants rewards have been specially given. In Burmah 5 to 20 rupees offered for alligators ; in special cases, more has been given in Bengal and Madras.

The difference in the amount of the rewards appears to indicate that higher sums were offered in special cases, probably when the creature was a netorious man or cattle-slayer.

Now I cannot help thinking that if Government made it part of the duty of district officers, not only to proclaim these rewards but to encourage the destruction of wild animals and snakes, by means of an organised establishment, which should be sumplied in these districts, much benefit might result. Tine money rewards already offered would probably suffice for wild animals, but those for venomous snakes should be increased. if, at the same time, the people were encouraged to work for the rewards, and were aided by persons acting under properly selected superiors, the result would soon show a diminution of the witd animals and snakes. But, I repeat that not until some organised establishment is formed, to be worked steadily throughout the whole country-not dependent on the will or subject to the caprice of individuals, but under local officers subject to one head-will any real or progressive amelioration of the evil be effected. Such a department under a selected officer, would, as was the case with the Thugs and Dacoits, soon make an impression on a death-rate which, so long as it continues in its present condition, must be referred to a defect in our administration.

J. FAYRER

\section{PALAEOLITHIC IMPLEMENTS OF NORTH-} EAST LONDON

IN 1855 Prof. Prestwich published in the Quarterly Fournal of the Geological Society an account of a fossiliferous deposit in the gravel of West Hackney. The precise locality of the excavation is given, and from I 855 to now many neighbouring excavations have been made. They almost invariably exhibit the "Palæolithic Floor." In 1855 only little was known of palæolithic implements, yet it is a remarkable thing that none of these objects, so common and well-made as they usually 